\title{
Academic Dishonesty of Muslim Students Using Rasch Model Measurement
}

\author{
Wahyu Hidayat ${ }^{1}$, Nur Asmawati Lawahid ${ }^{2}$ \\ \{wahyuhidayat@iainpare.ac.id ${ }^{1}$,nur_asmawati@iainpalu.ac.id $\left.{ }^{2}\right\}$ \\ Institut Agama Islam Negeri Parepare, Parepare, South Sulawesi, Indonesia ${ }^{1}$, Instutut Agama Islam \\ Negeri Datokarama Palu, Palu, Central Sulawesi, Indonesia ${ }^{2}$
}

\begin{abstract}
Academic dishonesty behavior of students has the potential to instigate corruption in the workforce. This study aims to measure the academic dishonesty of Muslim students using the Rasch measurement model. The participants involved are 566 Muslim students. The instrument of the study is the Academic Dishonesty Scale. Data were analyzed using the Rasch Model. The study found that academic dishonesty behavior that was easily carried out by Muslim students was copying and changing several sentences/lines/images/words and phrases from other sources $(-1.74 \log \mathrm{it})$, taking help from others to complete assignments (-1.63 log it), using online resources in assignments/personal education projects without quoting the author $(-1.57 \mathrm{log}$ it), and using body signals/cues to retrieve answers from friends ( $-1.50 \mathrm{log}$ it).The most frequent dimensions of academic dishonesty that is easily done by Muslim students, are plagiarism (-0.97 log it) and falsification (-0.51 log it).
\end{abstract}

Keywords: Academic Dishonesty, Muslim Students, Rasch Model.

\section{Introduction}

Honesty is a part of the integrity which forms the basic moral of an individual. Individuals are said to have integrity when they have honesty with themselves and others. Honesty must be one of the moral values possessed by individuals which describe the actual personality as it is. Traits such as; do not pretend, do not lie, follows the rules, do not cheat and treat others fairly, are some traits that defines an honest person. Similarly, a student must have an attitude of integrity and honesty, especially academic honesty.

The opposite of academic honesty is academic dishonesty. In some literature, researchers are more likely to use the term academic dishonesty compared to the term academic honesty $[1][2][3][4][5][6][7][8]$.

Academic dishonesty is a global phenomenon that is common in the academic world everywhere [9][10][11][12]. Academic dishonesty can have long-term adverse effects after graduating from university. Several studies have shown that students who have graduated tend to behave dishonestly in the workplace [13].

Several studies have shown that students' academic dishonesty behavior at universities is still high and increasing [14]. Likewise there are academic dishonesty study that shows, this trend applies to Muslim students [15][16].

Based on several studies, academic dishonesty still occurs among students. Therefore, this study aims to investigate academic dishonesty among Muslim students who take Islamic religious education study programs and non-Islamic religious education study programs. 


\subsection{Purpose of Study}

This study aims to obtain complete information on the academic honesty profile of Muslim students from various educational programs. More specifically, this study aims to study the honesty profile of Muslim students

\subsection{Academic Dishonesty}

Academic dishonesty is defined as an act or treatment that involves dishonesty in the academic field such as imitating, cheating, buying assignments, plagiarizing or claiming the work of others as one's own work [17]. Academic dishonesty defines academic dishonesty as the use of any material or assistance that is not permitted or permitted in carrying out academic assignments and assessments [18]. Academic dishonesty is a deliberate act of fraud or the use of false information in every academic outcome [19].

Academic dishonesty is deviant behavior and has a harmful impact on character development, and can jeopardize the integrity of academic institutions [20]. Academic dishonesty is an immoral act that can have an impact on those who commit it. The increase in academic dishonesty activities is very significant in the context of higher education today [14].

In the context of Islamic teachings, academic dishonesty is categorized as an act of fraud. Some prohibitions on academic dishonesty are mentioned in the Qur'anic verses, including the following:

And do not deprive people of their due and do not commit abuse on earth, spreading corruption (Qur'an, 26:183).

All scholars agree that cheating and plagiarism are not in accordance with Islamic teachings [7]. The Egyptian Fatwa Institute, Darul Ifta Al-Mishriyyah has adopted a fatwa on the practice of academic dishonesty as below[21]:

"The rights of written works and creative works are protected on a voluntary basis. The owner has the right to exploit these works. Other persons may not do injustice to their rights. Based on this opinion, the crime of plagiarism of intellectual rights and registered trademark rights, in claiming as one's work in public, is an act that is forbidden by syara'. This includes the prohibition of lying, forgery, embezzlement. This is a practice of neglect of the rights of others; and the practice of consuming other people's property by vanity."

Based on several explanations, it can be concluded that academic dishonesty is a deviant act in the academic field which is carried out by someone to get academic benefits from his actions.

\subsection{Forms of Academic Dishonesty}

The academic dishonesty includes cheating, plagiarism, and theft of ideas, whether published or unpublished[6]. The form of plagiarism that is, buying or copying other people's work and claiming to be their own work, copying answers from other people's papers during an exam, paying someone else to do an assignment [22]. Pavela (1993) mentions that there are four forms of academic dishonesty that is cheating using illegitimate material in exams, (2) using false information, references or data, (3) plagiarism, (4) giving answers to other exam participants [23].

The forms of academic dishonesty, such as using notes during an exam, copying answers from others during an exam, using dishonest methods, helping others commit fraud, copying other people's assignments and claiming the work himself, quoting without writing down references, falsifying bibliography, and using false reasons to delay the collection of assignments from lecturers [24]. Three forms of academic dishonesty in general, namely (1) giving, speaking and receiving information, (2) using prohibited materials, (3) utilizing 
people's weaknesses, procedures or processes to gain academic benefits [25]. Bashir and Bala who developed an instrument of academic dishonesty scale suggested that the characteristics of academic dishonesty were cheating / cheating during exams, plagiarism, asking for help from others, working with friends to cheat, falsify and lie in complementing assignments[26].

\section{Methods}

This research is a survey research with quantitative approach. This type of research is appropriate because it aims to describe the sample characteristics of a population [27]. Survey research is a data collection system to describe, compare, and explain knowledge, attitudes and behavior [28].

\subsection{Participants}

Participants in the study were 566 Muslim students consisting of 137 men and 429 women in the City of Pare pare, South Sulawesi, Indonesia. Participants were divided into two study programs namely Islamic religious education and non-Islamic religious education.

\subsection{Instrumentation}

The instrument for measuring dishonesty was adapted from Hilal Bashir and Ranjan Bala who developed the Academic Dishonesty Scale (ADS) measurement tool. The ADS instrument has a high internal consistency value $\alpha=0.831$ [26]. The ADS instrument was translated to Indonesian for ease of getting response. The instrument includes six constructs in measuring academic dishonesty, namely cheating in examinations, plagiarism, seeking outside help, prior cheating, falsification, and lying about academic assignments (falsification), and lying about academic assignments. The instrument scale is a Likert scale with five answer options namely: never, rarely, sometimes, often, and always

\subsection{Data Analysis}

The Rasch Model technique is used to analyze measurement results. The basic principle underlying the Rasch model is the probability of respondents to answer any item correctly based on the item's difficulty and the respondent's ability [29], [30], [31][40] [41].

\section{Results and Discussion}

This section explains the description of academic dishonesty in Muslim students using Rasch Model analyses techniques. The description of academic dishonesty of Muslim students is divided into participant profiles, person reliability, separation, logit items and undimensionality. Table 1 shows the participant profile.

Table 1. Participant's profile.

\begin{tabular}{ll}
\hline \multicolumn{1}{c}{ Category } & \multicolumn{1}{c}{ Description } \\
\hline Gender & Male $=137(24.2 \%)$ \\
& Female $=429(75.8 \%)$ \\
Study program & Islamic studies $=303(53.5 \%)$ \\
\hline
\end{tabular}




\subsection{Person Reliability and Separation}

Participant reliability (Person Reliability) is the consistency of the Muslim student in answering the instrument items. Consistencies of responses by the Muslim students to the measurement of academic honesty are shown in table 2 .

Table 2. Summary of Statistical Item and Person Reliability.

\begin{tabular}{ccccc}
\hline & Mean & Separation & Reliability & $\begin{array}{c}\text { Cronbach } \\
\propto\end{array}$ \\
\hline Person & -2.43 & 2.73 & 0.76 & 0.81 \\
Item & 0.00 & 10.90 & 0.99 & \\
\hline
\end{tabular}

Table 2 illustrates the average participant logit is -2.43 logit which shows that all Muslim students tend to be honest in academics. Respondents' strata values are indicated by the separation values. The strata person value of 2.7 or 3 shows that the Muslim students are divided into three large groups, namely groups of participants who tend to have academic honesty, the second group is in the middle (close to the average logit) who sometimes are honest and sometimes are dishonest in their academics endeavors, and the third group tends to be dishonest in academics.

\subsection{Academic Honesty Measurement}

Academic honesty measurement is measured with 23 items of academic honesty scale. Aspects related to academic dishonesty of Muslim students are shown in table 3.

Table 3. Descriptions of Academic Dishonesty of Muslim Undergraduates.

\begin{tabular}{|c|c|c|c|}
\hline Item & Statements & Measure & $\begin{array}{c}\text { Model } \\
\text { S.E }\end{array}$ \\
\hline F18 & $\begin{array}{l}\text { Damaging library books so that classmates don't } \\
\text { get the required content }\end{array}$ & 2.75 & 0.28 \\
\hline Ly22 & $\begin{array}{l}\text { Paying someone to write an answer / assignment / } \\
\text { homework assignment }\end{array}$ & 2.42 & 0.24 \\
\hline CE3 & $\begin{array}{l}\text { Change other books to get better grades during } \\
\text { the exam }\end{array}$ & 1.68 & 0.16 \\
\hline Ly 21 & $\begin{array}{l}\text { Buy a project / assignment online and claim it as a } \\
\text { one's work }\end{array}$ & 1.09 & 0.11 \\
\hline F17 & $\begin{array}{l}\text { Submit assignments on one's name but prepared } \\
\text { by friends }\end{array}$ & 1.05 & 0.11 \\
\hline PC16 & Encourage other classmates to commit fraud & 0.98 & 0.11 \\
\hline $\mathrm{OH} 10$ & Bribing & 0.86 & 0.1 \\
\hline Ly23 & $\begin{array}{l}\text { Give untrue reasons to the lecturer, to get extra } \\
\text { time on the project /assignment }\end{array}$ & 0.49 & 0.08 \\
\hline CE4 & $\begin{array}{l}\text { During tests, tear up the answers on the question } \\
\text { paper, then hand it over to classmates }\end{array}$ & 0.35 & 0.08 \\
\hline F19 & $\begin{array}{l}\text { Submit the same assignment more than once to } \\
\text { the same subject }\end{array}$ & 0.17 & 0.07 \\
\hline
\end{tabular}




\begin{tabular}{|c|c|c|c|}
\hline $\mathrm{OH} 12$ & $\begin{array}{l}\text { Using unfair methods to get information about the } \\
\text { exam }\end{array}$ & 0.06 & 0.07 \\
\hline Ly20 & $\begin{array}{l}\text { Give untrue explanation when the task is past the } \\
\text { deadline. }\end{array}$ & -0.18 & 0.06 \\
\hline PC14 & $\begin{array}{l}\text { Write answers on the desk / wall / hand / paper } \\
\text { before the exam time starts }\end{array}$ & -0.19 & 0.06 \\
\hline PL9 & $\begin{array}{l}\text { Manipulate scientific information on the internet } \\
\text { and claim to be personal writing }\end{array}$ & -0.22 & 0.06 \\
\hline PL6 & $\begin{array}{l}\text { Copy a sentence from a textbook and claim it as a } \\
\text { personal work }\end{array}$ & -0.35 & 0.06 \\
\hline PC15 & $\begin{array}{l}\text { Swapping seats near academically advanced } \\
\text { friends to get better grades on the exam. }\end{array}$ & -0.72 & 0.05 \\
\hline CE5 & $\begin{array}{l}\text { During the exam I tried copying answers from } \\
\text { other people }\end{array}$ & -1.10 & 0.05 \\
\hline $\mathrm{OH} 13$ & $\begin{array}{l}\text { Trying to find out the questions in the exam } \\
\text { before it begins }\end{array}$ & -1.34 & 0.05 \\
\hline CE2 & $\begin{array}{l}\text { Use prohibited items such as hidden notes, } \\
\text { calculators and other electronic devices during the } \\
\text { exam }\end{array}$ & -1.36 & 0.05 \\
\hline CE1 & $\begin{array}{l}\text { Use signals / body cues to get answers from } \\
\text { friends }\end{array}$ & -1.50 & 0.05 \\
\hline PL8 & $\begin{array}{l}\text { Use online resources in personal education } \\
\text { assignments / projects without quoting the author. }\end{array}$ & -1.57 & 0.05 \\
\hline OH11 & Get help from others to complete the task & -1.63 & 0.05 \\
\hline PL7 & $\begin{array}{l}\text { Copy and change several sentences / lines / } \\
\text { images / words and phrases from other sources }\end{array}$ & -1.74 & 0.05 \\
\hline
\end{tabular}

Table 3 shows that actions which tend to be difficult for students in academic activities, namely damaging library books $(2.75 \mathrm{log}$ it), paying someone to write an answer/assignment/homework (2.42 log it), replacing other books to get more grades good at the test $(1.68 \log$ it). Whereas some actions that tend to be easy to do are copy and change some sentences/lines/images/words and phrases from other sources (-1.74 log it), get help from others to complete tasks (-1.63 log it), use online resources in assignments/personal education project without quoting the author (-1.57 log it), and using body signals/cues to take answers from friends $(-1.50 \mathrm{log}$ it).

Overall the level of academic dishonesty of Muslim students from easy to difficult based on the dimensions is shown in table 4. The dimensions of academic dishonesty are plagiarism, help from others, cheating on exams, cheating on friends, lying on academic assignments and falsification.

Table 4. Level of Participants' Honesty According to the Dimensions

\begin{tabular}{lc}
\hline Dimensions & Means of Difficulty (logit) \\
\hline Plagiarism & -0.97 \\
Outside help & -0.51 \\
Cheating in Examination & -0.39 \\
Prior Cheating & +0.02 \\
Lying about Academic Assignments & +0.95 \\
Falsification & +1.32 \\
\hline
\end{tabular}


Table 4 shows that academic dishonesty that is done or often done by Muslim students. Plagiarism and falsification are forms of dishonesty that are difficult or rarely practiced by Muslim students. However, other academically dishonest acts that Muslim students tend to do a lot are asking for help from others both in exams and in lectures, and cheating / cheating during exams.

\subsection{Unidimensionality of Participants (person)}

Participants' unidimensionality aims to find out whether the participants' responses can be measured by an academic honesty scale instrument. In this case the Rasch analysis model uses the Principal Component Analysis (PCA) of the residual, which measures the extent of the diversity of the response. Unidimensionality of participants' response is shown in table 5.

Table 5. Unidimensionality of participants' response (Standardized Residual Variance)

\begin{tabular}{|c|c|c|c|c|c|}
\hline Dimensions & & 1piri & & & Modeled \\
\hline Total raw variance in observation & $=$ & 1041.6 & $\begin{array}{c}100.0 \\
\%\end{array}$ & & $100.0 \%$ \\
\hline $\begin{array}{l}\text { Raw variance explained by } \\
\text { measures }\end{array}$ & $=$ & 486.6 & $\begin{array}{c}46.7 \\
\%\end{array}$ & & $48.6 \%$ \\
\hline Raw variance explained by persons & $=$ & 76.1 & $7.3 \%$ & & $7.6 \%$ \\
\hline Raw variance explained by items & $=$ & 410.4 & $\begin{array}{c}39.4 \\
\%\end{array}$ & & $41.0 \%$ \\
\hline Raw unexplained variance (total) & $=$ & 555.0 & $\begin{array}{c}53.3 \\
\%\end{array}$ & $\begin{array}{c}100.0 \\
\%\end{array}$ & \\
\hline Unxplned variance in 1 st contrast & $=$ & 57.3 & $5.5 \%$ & $\begin{array}{c}10.3 \\
\%\end{array}$ & \\
\hline Unxplned variance in 2 nd contrast & $=$ & 51.2 & $4.9 \%$ & $9.2 \%$ & \\
\hline Unxplned variance in 3 rd contrast & $=$ & 46.0 & $4.4 \%$ & $8.3 \%$ & \\
\hline Unxplned variance in 4 thcontrast & $=$ & 39.7 & $3.8 \%$ & $7.2 \%$ & \\
\hline Unxplned variance in 5 th contrast & $=$ & 34.0 & $3.3 \%$ & $6.1 \%$ & \\
\hline
\end{tabular}

Table 5 shows the results of the measurement of diversity (raw variance) data is $46.7 \%$, which is not much different from the expected value of $48.6 \%$. This shows that the minimum requirement of $20 \%$ unidimensionality is met. At the same time the Rasch unidimensional limit is fulfilled, which is above $40 \%$ (Linacre, 2011). Another thing that supports the result is the unexplained variance which is under $7 \%$. This shows the level of independence of participants in the analyses is good.

\section{Conclusion}

The study shows that there are still dishonest acts in academics committed by Muslim students. This study reinforces that the practice of academic dishonesty in Muslim students is still relatively high and significant [32][33][34].

In the context of the practice of academic dishonesty carried out by Muslim students in this study shows the practice of plagiarism, cheating and asking for help from friends. 
Plagiarism, cheating and asking for help from friends are forms of academic dishonesty [16], [30][35].

This practice was also mentioned done by Ramlan, Zaharah \& Saedah [7]. They contend that the practice of academic dishonesty among Muslim students includes those related to the main lecture assignments relating to; plagiarism activities, not making appropriate references and taking material from others without giving the author the credit.

\section{References}

[1] H. Iberahim, N. Hussein, N. Samat, F. Noordin, and N. Daud, "Academic Dishonesty: Why Business Students Participate in these Practices?," Procedia - Soc. Behav. Sci., vol. 90, no. October, pp. 152-156, 2013, doi: 10.1016/j.sbspro.2013.07.076.

[2] L. Dömeová and A. Jindrová, "Unethical behavior of the students of the Czech university of life sciences," Int. Educ. Stud., vol. 6, no. 11, pp. 77-85, 2013, doi: 10.5539/ies.v6n11p77.

[3] M. a. Vandehey, G. M. Diekhoff, and E. E. LaBeff, "College cheating: A twenty-year follow-up and the addition of an honor code," J. Coll. Stud. Dev., vol. 48, no. 4, pp. 468-480, 2007, doi: 10.1353/csd.2007.0043.

[4] D. L. McCabe, "Cheating among college and university students: A North American perspective," Int. J. Educ. Integr., vol. 1, no. 1, 2005, doi: 10.21913/ijei.v1i1.14.

[5] M. K. Galloway, "Cheating in Advantaged High Schools: Prevalence, Justifications, and Possibilities for Change," Ethics Behav., vol. 22, no. 5, pp. 378-399, Sep. 2012, doi: 10.1080/10508422.2012.679143.

[6] D. L. R. Jones, “Academic Dishonesty: Are More Students Cheating?," Bus. Commun. Q., vol. 74, no. 2, pp. 141-150, Jun. 2011, doi: 10.1177/1080569911404059.

[7] R. Mustapha, "Ketidakjujuran Akademik Dalam Kalangan Mahasiswa di Malaysia: Analisis Perbandingan Tahun 2014-2015,” J. Kurikulum dan Pengajaran Asia Pasifik, vol. 4, no. 1, pp. 41$55,2016$.

[8] M. W. M. Williams and M. N. Williams, "Academic Dishonesty, Self-Control, and General Criminality: A Prospective and Retrospective Study of Academic Dishonesty in a New Zealand University," Ethics Behav., vol. 22, no. 2, pp. 89-112, Mar. 2012, doi: 10.1080/10508422.2011.653291.

[9] A. Chudzicka-Czupała et al., "Application of the Theory of Planned Behavior in Academic Cheating Research-Cross-Cultural Comparison," Ethics Behav., vol. 26, no. 8, pp. 638-659, Nov. 2016, doi: 10.1080/10508422.2015.1112745.

[10] K. Briggs, J. P. Workman, and A. S. York, "Collaborating to cheat: A game theoretic exploration of academic dishonesty in teams," Academy of Management Learning and Education, vol. 12, no. 1. Academy of Management Briarcliff Manor, NY, pp. 4-17, 01-Mar-2013, doi: 10.5465/amle.2011.0140.

[11] A. M. Imran and M. S. Nordin, "Predicting the Underlying Factors of Academic Dishonesty among Undergraduates in Public Universities: A Path Analysis Approach," J. Acad. Ethics, vol. 11, no. 2, pp. 103-120, Jun. 2013, doi: 10.1007/s10805-013-9183-x.

[12] S. C. Yang, C. L. Huang, and A. S. Chen, "An investigation of college students' perceptions of academic dishonesty, reasons for dishonesty, achievement goals, and willingness to report dishonest behavior," Ethics Behav., vol. 23, no. 6, pp. 501-522, 2013, doi: 10.1080/10508422.2013.802651.

[13] M. S. Nazir and M. S. Aslam, "Academic dishonesty and perceptions of Pakistani students," Int. J. Educ. Manag., vol. 24, no. 7, pp. 655-668, 2010, doi: 10.1108/09513541011080020.

[14] P. G. Lewellyn and L. C. Rodriguez, "Does Academic Dishonesty Relate to Fraud Theory? A Comparative Analysis,” Am. Int. J. Contemp. Res., vol. 5, no. 3, pp. 1-6, 2015.

[15] W. Hidayat, J. Bin Ahmah, and M. I. Bin Hamzah, "Religion Fundamentalism in Islamic Students," Int. J. Acad. Res. Bus. Soc. Sci., vol. 8, no. 1, pp. 372-382, 2018, doi: 10.6007/ijarbss/v8-i1/3814. 
[16] Ramlan Mustapha and Nik Asilah Nik Ali, "An Empirical Survey of an Academic Dishonesty At a Major Public Universities in Recent Years: The Malaysian Evidence," Asian J. Educ. Res., vol. 5, no. 3, pp. 43-49, 2017.

[17] L. A. Shafie and S. Nayan, "The Net Generation and Academic Dishonesty in Malaysia," Technol. Innov. Educ., pp. 181-186, 2008.

[18] "Psychology of academic cheating. - PsycNET." [Online]. Available: https://psycnet.apa.org/record/2006-21815-000. [Accessed: 04-Sep-2020].

[19] "Collegiate Academic Dishonesty Revisited:What Have They Done, How Often Have They Done It, Who Does It, And Why Did They Do It?" [Online]. Available: https://www.sociology.org/ejsarchives/vol7.4/lambert_etal.html. [Accessed: 04-Sep-2020].

[20] R. Jurdi, H. S. Hage, and H. P. H. Chow, "CSSHE SCÉES Academic Dishonesty in the Canadian Classroom: Behaviours of a Sample of University Students," Dec. 2011.

[21]“Dar al-Iftaa | المصرية [Online]. Available: https://www.daralifta.org/ViewFatwa.aspx?ID=426. [Accessed: 04-Sep-2020].

[22] S. L. Murphy, M.M., \& Banas, Character Education Overcoming Prejudice. New York: Chelsea House publisher, 2009.

[23] G. Pavela, "Academic Integrity: What the Latest Research Shows," Synth. Law Policy High. Educ., vol. 5, pp. 340-349, 1993.

[24] B. Hendricks, "Academic Dishonesty: A Study in The Magnitude of and Justification for Academic Dishonesty Among College Undergraduate and Graduate Students," J. Coll. Stud. Dev., vol. 35, pp. 212-260, 2004.

[25] G. J. Cizek, Detecting and preventing classroom cheating: Promoting integrity in assessment. Corwin Press, 2003.

[26] H. Bashir, "Development and Validation of Academic Dishonesty Scale ( ADS ): Presenting a Multidimensional Scale," vol. 11, no. 2, pp. 57-74, 2018.

[27] E. \& T. Groves, Robert M., Fowler, Floyd J., Couper, Mick P., Lepkowski, James W., Singer, Survey Methodology. John Willey \& Sons, 2004.

[28] Wahyu Hidayat and Nurasmawati Lawahid, Metode Fuzzy Delphi Untuk Penelitian Sosial. Bandung: Alfabeta, 2020.

[29] D. Andrich, "Sufficiency and Conditional Estimation of Person Parameters in the Polytomous Rasch Model," Psychometrika, vol. 75, no. 2, pp. 292-308, 2010.

[30] Wahyu Hidayat; Sri Mulianah; Mujahidah., "Analysis of The National Character Senior High School Students by Using Rasch Model," in Proceedings of the First International Conference on Religion and Education, 2019, pp. 1-9.

[31] Trevor G. Bond and Christine M.Fox, Applying the Rasch Model: Fundamental Measurement in the Human Sciences. New York: Routledge., 2015.

[32] A. . Moten, "Academic dishonesty and Misconduct: Curbing plagiarism in the Muslim world," Intellect. Discourse, vol. 22, no. 2, pp. 168-189, 2014.

[33] S. K. Vlaardingerbroek, B., Shehab, S. S., \& Alameh, "The problem of open cheating and invigilator compliance in the Lebanese brevet and baccalauréat examinations," Int. J. Educ. Dev., vol. 31, no. 3, pp. 297-302, 2011, doi: 10.1016/j.ijedudev.2010.03.002.

[34] Wahyu Hidayat; Jamil bin Ahamd; Isa bin Hamzah., "Nilai keutamaan pengetahuan dan kebijaksanaan dalam konteks pendidikan karakter bangsa," J. Penelit. dan Eval. Pendidik., vol. 22, no. 1, pp. 82-91, 2018.

[35] D. L. R. Jones, “Academic dishonesty: Are more students cheating?,” Bus. Commun. Q., vol. 74 , no. 2, pp. 141-150, 2011, doi: 10.1177/1080569911404059. 